Gi respons på artikler gjennom artiklenes kommentarfelt på tidsskriftet.no.

Innleggene publiseres fortløpende på Tidsskriftets nettside og et utvalg

av innleggene publiseres også i papirutgaven i spalten «Brev til redaktøren».

Redaksjonen forbeholder seg retten til å foreta redaksjonelle endringer.

Forfattere av vitenskapelige artikler har tilsvarsrett, jf. Vancouver-gruppens regler.

\section{Re: Det er så mye vi ikke vet}

Tveito skriver om steile fronter i fora der kronisk utmattelsessyndrom/myalgisk encefalopati blir diskutert (1). Så lenge arbeidet med å finne årsak og behandling av tilstanden splittes mellom to fronter i helsevesenet, så vil det også naturligvis finnes to fronter i helsedebatten. Slik jeg oppfatter det har Henrik Vogt med flere proklamert seg selv som diskusjonens elite, med utgangspunkt i at tilstanden kan behandles med et psykiatrisk utgangspunkt. Etter min mening er det kun tilfeldigheter som har gjort at pasienter med psykiatrisk behandling har vist bedring. En antagelse om at dette må gjelde hele gruppen er et stort feilgrep. Sammenblanding av årsak og konsekvens kan være fatalt.

Som ME-pasient har jeg holdt på med kognitiv terapi i 12 år og kun oppnådd bedring av enkelte symptomer, men ikke den unormale muskulære trettheten eller smertene. Hverdagen har blitt til det beste jeg kan forvente.

For å oppnå et bedre liv med de kunnskapene vi i dag har, ser jeg det som nødvendig å følge begge retninger. Den psykiske for å bedre hverdagen, og den fysiske for å bli frisk. Veien til en bedre hverdag kan være meget lang og dreie seg om flere år for mange. Dagens syn på tilrettelegging og opptrening er altfor kortsiktig, og med tvang og oppildnet positiv motivering, kan smertene fort bli verre og veien lengre. Det er da pasientgruppen stritter imot som mest, og frontene tilspisser seg.

En løsning for å lette på frontenes hete krig, er å begrave stridsøkser og arbeide i fellesskap med lik respekt for hverandres motivasjon om å gjøre hverdagen bedre for pasientene. Men allikevel, uten å lytte til pasientenes reaksjoner, er vi like langt.

Øistein Jansen
oija@online.no

Øistein Jansen (f. 1961) er pasient.

Ingen oppgitte interessekonflikter.

Litteratur

1. Tveito K. Det er så mye vi ikke vet. Tidsskr Nor Legeforen 2014; 134: 1117

\section{Re: Det er så mye vi ikke vet}

Takk for en fin leder om en problematisk helsetilstand som opptar allmennheten, og som i særlig grad utfordrer medisinfaget (1). Lederen trekker fram flere sider ved diagnosen kronisk utmattelsessyndrom/myalgisk encefalopati (CFS/ME), og det stilles flere viktige spørsmål, blant annet om den tradisjonelle biomedisinske, reduksjonistiske modell er egnet til å forstå problemet og gjøre oss i stand til å hele det.

«Det er så mye vi ikke vet» og «kanskje ligger svaret et annet sted enn vi kan forestille oss», skriver Tveito. Her savner jeg at erfaringsperspektivet nevnes mer eksplisitt, som en viktig del av dette omfattende problemet: Det vil si hvordan skjellsettende livserfaringer i menneskers historie og nåværende livssituasjon kan påvirke «den levde kroppen», svekke den og gjøre den syk, for å bruke uttrykket til den franske filosofen Merleau-Ponty (2). Den mangeårige forskningen til Anna Luise Kirkengen gir en grundig dokumentasjon av dette (3).

Jeg har skrevet en artikkel i tidsskriftet til Det Norske Medicinske Selskab, Michael Quarterly, som gir en gjennomgang av dette perspektivet med kronisk utmattelsessyndrom-diagnosen som en «rød tråd» (4). Artikkelen gir også utfyllende svar og tolkninger på noen av de spørsmålene som Tveito stiller.

Jeg ser det som nødvendig at forskning med det målet å få fram ulike hypoteser og mer kunnskap omkring CFS/ME, også innbefatter å undersøke biografiske «data» om menneskers erfaringer. Det vil kunne bringe oss viktige skritt videre i å forstå tilstanden og kunne gi hjelp som nytter.

\section{John-Tore Eid}

john-tore.eid@ntnu.no

John-Tore Eid (f. 1952) er stipendiat ved Institutt for Samfunnsmedisin, NTNU

Ingen oppgitte interessekonflikter.

\section{Litteratur}

1. Tveito K. Det er så mye vi ikke vet. Tidsskr Nor Legeforen 2014: 134: 1117.

2. Merleau-Ponty M. Phénoménologie de la perception. Paris: Gallimard, 1945

3. Kirkengen AL. Hvordan krenkede barn blir syke voksne. 2. utg. Oslo: Universitetsforlaget, 2009. English translation: Kirkengen AL. The lived experience of violation. How abused children become unhealthy adults. Bucuresti: Zeta Books, 2010

4. Eid JT. Levd kropp - en analyse av Anna Luise Kirkengens tenkning. Michael 2012; 9: 254-67

\section{Re: Akutt promyelocyttleukemi}

Dette var en fin og kortfatta oversikt. Jeg vil bare kommentere at det cytogenetiske avviket nå er klassifisert som translokasjon $(15 ; 17)$ (q24.1, q21.1) PML-RARA, ikke lenger translokasjon (q22, q21), som artikkelen angir. Dette er korrigert i den oppdaterte versjonen av WHO-klassifikasjonen (2).

\section{Nessar Ahmad Azrakhsh \\ nessazr@gmail.com}

Nessar Ahmad Azrakhsh (f. 1978) er lege i spesialisering ved Sykehuset Telemark HF, Medisinsk avdeling Skien.

Ingen oppgitte interessekonflikter.

\section{Litteratur}

1. Reikvam H, Hovland R, Bruserud $\emptyset$. Akutt promyelocyttleukemi. Tidsskr Nor Legeforen 2014; 134: 1052-5

2. Swerdlow SH, Campo E, Harris NL et al. World Health Organization Classification of tumours of haematopoietic and lymphoid tissues. Lyon: IARC Press, 2008.

\section{Re: Antiepileptika og medfødte misdannelser}

Karl Otto Nakken og medarbeidere rapporterer i denne artikkelen (1) norske resultater fra EURAP-studien (2), hvor målet er «å kartlegge risikoen for større føtale misdannelser som følge av bruk av antiepileptika i svangerskapet samt finne ut hvilke legemidler som er tryggest under graviditet».

De norske resultatene viser en forekomst av «større medfødte misdannelser» på 4,5\%, som er høyere enn det som rapporteres av «alvorlige medfødte misdannelser» i Medisinsk fødselsregister (MFR): 2,6\% i 2011. Forfatterne mener disse tallene ikke er direkte sammenlignbare «ettersom malformasjonsraten i registeret er basert på antall misdannelser som blir oppdaget før barnet utskrives 